\title{
ARE SOCIAL ECONOMY ORGANIZATIONS A VIABLE ALTERNATIVE ON THE LABOUR MARKET FOR STUDENTS FROM NON-ECONOMIC FIELDS OF STUDY? RESEARCH RESULTS
}

\author{
Janusz Reichel* Agata Rudnicka, Błażej Socha
}

University of Łódź, Poland

\begin{abstract}
Labour market is getting more and more diverse. Young people have broad spectrum of possibilities to plan and develop their future careers. Future graduates may put attention on different opportunities from huge corporations to local non-governmental organizations. One of still underestimated sectors as a working place is the social enterprise sector. The current debate of the labour market is focusing on the issue of competences needed to meet the needs of a highly competitive labour market. The idea of entrepreneurship is also a focal point for these considerations. The main aim of the paper is to present the analysis of choices for career development among students from non-economic fields of study. The research was conducted among students of non-economics majors in the University of Lodz, Poland. Authors were seeking the answer to the question of whether the social economy organizations are treated as a potential workplace. The main results of the study confirm that the social economy sector is not the priority as a future choice for career development.
\end{abstract}

Keywords: non-economic studies, social entrepreneurship, career development, competences

\section{Introduction}

The current situation on the Polish labour market seems to be quite stable, as evidenced by e.g. fairly low unemployment rate $6.6 \%$ by the end of 2017 (GUS, 2018). On the other hand, Poland, like other countries, should prepare for emerging trends related to the labour market, such as basic income, automation and robotics and their impact on employment (Stewart, De and Cole, 2014; Bitner, Starościk and Szczerba, 2016) or rapidly changing competences that employees should have. According to Frey, Osborne and Holmes (2016), in OECD countries, 57\% of jobs are at risk because of automation. In Poland, around 7.5 million jobs ( $45 \%$ of all jobs on the labour market) can be potentially replaced by robots and algorithms (Ratajczak, 2017). The industry 4.0 may reshape the professional skills and cause that new non automatic job opportunities will appear (Eberhard et al., 2017). This triggers a debate on the key competences of the labour market and the possibilities of finding a job for new employees who will support the labour market. What is more important is the issue of entrepreneurship, its understanding and the possibility of using entrepreneurial skills to create a friendly and inclusive labour market.

Despite the fact that the situation on the employee's market is good, expectations towards employees are growing (0czekiwania pracodawców wobec..., 2016). Employers are looking for people who have both specialist skills and soft skills needed to conduct relationships with others. The conditions of people entering the labour market are diversified. While graduates of economic and business studies usually have the opportunity to acquire knowledge about entrepreneurship and management, graduates of non-economic majors have such possibilities rather limited.

The situation of graduates ending non-economic studies is different on the labour market. There are signals from the labour market which report that business is getting open for graduates of humanistic fields of study (Gazeta Prawna, 2017) but the general overview for non-economic studies is not satisfactory (Wyborcza.pl, 2017).

This situation requires the analysis of the labour market taking into account the employment opportunities offered not only by business sectors but also by non-business sectors and in particular non-profit organizations. Future employees should have access to the knowledge about job opportunities not only in places as obvious to the labour market as enterprises, public administration or schools but also in social enterprises. The role of social enterprises as an element of the labour market seems to be more and more appreciated (Defourny and Nyssens, 2008; Borzaga et al., 2014; Haugh, 2005). The question is whether students are also aware that the labour market is diverse and that social enterprises can be the place for the development of their careers. The aim of the paper was to assess the situation of the students from non-economic studies regarding their future job choices in different sectors with special attention to social enterprises.

Taking into account the dynamics of processes on the labour market, it is worth considering the issue of its diversity including different sectors. Boundaries among particular types of organizations have been wiped out in recent years. This is due to, among others, the professionalization of the third sector and building its economic potential (Stankiewicz and Seiler, 2013) on one hand, as well as the aspirations of business organizations to create social capital and, more than ever, to consider social and environmental issues in their business models (Visser, 2010; Carroll and Shabana, 2010) on the other. The picture below illustrates the boundaries among the sectors and the diversity of organizations that can be considered as future work places.

A competitive job market means that not everyone will be able to find the opportunity to develop their career life in the planned profession. It results in the necessity to improve skills or to take up employment in other sectors. One of them is the non-governmental sector with social enterprises. Regarding the discussion about this sector, it is worth mentioning the development of social enterprises. NGOs and social economy have much in common; e.g. social mission, using social innovation to achieve their own goals, reinvestment of funds for social purposes etc. Social economy, similarly to the traditionally understood sector of non-governmental organizations, goes beyond the public sector (state) and outside the private sector (market). It can be understood as a: "tool for economic and social mobilization of neglected local communities/areas" and the formula of "increasing the participation of their members/residents in economic and public life exchange" (Kaźmierczak 


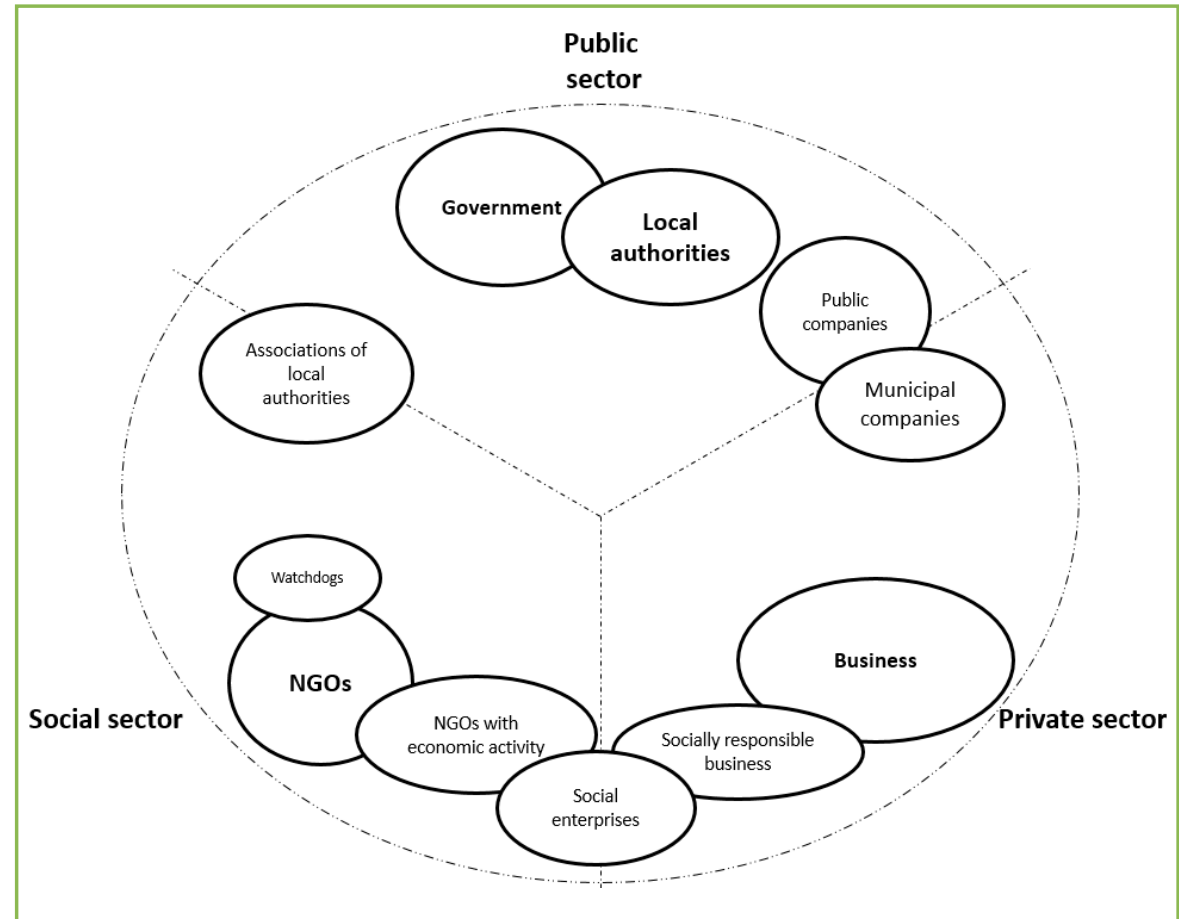

Figure 1 Hybrid spectrum of organizations as labour market opportunities Source: Reichel, 2018

and Rymsza, 2007). These are very diverse activities from social reintegration to professional organizations active in environmental protection, economic democracy, rebuilding civil attitudes etc. (Leś, 2005). Social enterprises are mainly organizations that run a business with a certain risk. In addition, next to the economic activity, they set social goals and invest generated surpluses - depending on these goals - in their own activities or in the community and are not guided by the need to achieve maximum profit for the owners (shareholders) (Branco, 2007). In some countries like Poland, different types of NGOs that undertake economic activities are also perceived as social enterprises.

The data about the employment in NGOs are not as optimistic as about business organizations but they show that there is a potential for this sector of the labour market. Employment in non-profit organizations based on employment contracts was 162,000 people $(1.06 \%$ of the labour market) whereas employment (employment contracts) in the social sector in Poland was around 462,000 people (3\% of the labour market) in 2016. It shows that this sector is relatively small nowadays. However, it should be noted that social sector in Belgium, France, Luxemburg and Netherlands, compared to total paid employment, is approx. 9\% (Monzón and Chaves, 2017). We can therefore suppose that this sector will grow only if Poland economy develops in the way typical for western economies. New trends on the labour market can also change the current structure of employment in favour of social organisations.

Literary sources mention top three most probable main trends generating jobs in near future: higher investment in health and education thanks to rising incomes; more healthcare related jobs because of aging population and jobs related to development and deployment of new technologies (Manyika et al., 2017; MGI, 2017). It could potentially turn people's attention to the non-profit and social economy sectors: non-governmental organizations and social enterprises, especially those that deal with health problems and elderly people.

\section{Material and methods}

For the purpose of the study, a research survey was designed and conducted among students of the $3^{\text {rd }}$ year of bachelor studies and the second year of complementary master studies in non-economics majors at the University of Łódź, Poland. The survey questionnaire was made available in December 2017 in the form of an electronic questionnaire. The survey was completed by 134 respondents and the ratio of filled questionnaires to all that entered the survey page was 37\%. In order to achieve the research goal, a standard statistical analysis of results was performed, Kendall's Tau-b Correlation Coefficient was used to measure the strength and direction of association that exists between two variables measured on an ordinal scale and Mann-Whitney $U$ test was performed to identify differences in distribution among groups of students. Parallelly, a similar survey was conducted with students from economics majors and some comparisons are made when discussing and concluding the results.

\section{Results and discussion}

The majority of the surveyed students associated their professional plans with the business sector (48.51\%). $22.39 \%$ of the respondents would like to work in the SMEs sector. $14.18 \%$ of the surveyed students would like to be employed in corporations. That means that more than $36 \%$ of the students plan to be an employee in a business sector. About $12 \%$ of them declared to be self-employed. $33.58 \%$ of the respondents are interested in work outside the business sector. The majority of them would like to work in public administration sector (10.45\%) and in the higher education sector (7.46\%). From among $17.91 \%$ of the respondents who responded "other", there are people who do not have specific plans for the future and those who want to work as teachers. Only $3.73 \%$ of the respondents plan to work in non-governmental organizations. The research also shows that combination of studying with professional work significantly affects students career plans ( $p$-value 0.025). The group of students who combine studying and professional work plan to set up their own business and work in corporations more often than the group of students who only study.

The surveyed students were asked about their preferable factors that determine the choice of an employer (see Table 1).

The most frequent factors chosen by the students determining the choice of an employer are as follows: salary, a clear division of responsibilities, the employer's compliance with ethical standards and the atmosphere at work. This means that for students, work related factors are still the most important ones. Despite the fact that majority of factors related to CSR (Corporate Social Responsibility) are assessed at relatively low level (e.g. activities for environmental protection, social projects run by the employer), the employer's honesty and compliance with ethical standards are one of the most important factors determining students' choices.

In the next question, students were asked to declare their entrepreneurial competences (see Table 2). 
Table 1 Factors determining the choice of an employer (where 1 denotes: totally not important; 7 denotes: very important)

\begin{tabular}{|c|c|c|}
\hline No. & Factor & Mean \\
\hline 1 & The distance from the place of residence & 4.50 \\
\hline 2 & Easy and fast access to the workplace & 4.90 \\
\hline 3 & Salary & 6.28 \\
\hline 4 & Social package (fitness card, additional health insurance etc.) & 4.21 \\
\hline 5 & Company car & 2.45 \\
\hline 6 & Company mobile & 2.42 \\
\hline 7 & The atmosphere at work & 6.04 \\
\hline 8 & A clear division of responsibilities & 6.19 \\
\hline 9 & Democratic management style & 4.84 \\
\hline 10 & Organizational values consistent with personal values & 5.19 \\
\hline 11 & Social projects run by the employer (sponsoring, volunteering etc.) & 3.18 \\
\hline 12 & Activities for environmental protection & 3.41 \\
\hline 13 & The image of the employer & 4.75 \\
\hline 14 & Opinions of other employees & 4.91 \\
\hline 15 & $\begin{array}{l}\text { Opinions of the stakeholders (local community, non-governmental } \\
\text { organization etc.) }\end{array}$ & 4.41 \\
\hline 16 & The employer's honesty and compliance with ethical standards & 6.11 \\
\hline
\end{tabular}

Table 2 Entrepreneurial competences (where 1 denotes: I do not have skills in that the area; 7 denotes: I do have excellent skills in the area)

\begin{tabular}{|l|c|c|}
\hline No. & Factor & Mean \\
\hline $\mathbf{1}$ & The ability to take a risk & 4.12 \\
\hline $\mathbf{2}$ & The ability to analyse the market/ environment & 4.12 \\
\hline $\mathbf{3}$ & Creativity & 5.15 \\
\hline $\mathbf{4}$ & Self-improvement skills & 5.55 \\
\hline $\mathbf{5}$ & Negotiation skills & 4.47 \\
\hline $\mathbf{6}$ & Leadership skills & 4.60 \\
\hline $\mathbf{7}$ & The ability to build a professional network of contacts & 4.07 \\
\hline $\mathbf{8}$ & Effective management & 4.36 \\
\hline $\mathbf{9}$ & Cooperation with others & 5.25 \\
\hline $\mathbf{1 0}$ & The ability to advise & 5.19 \\
\hline 11 & The ability to identify others'needs & 4.92 \\
\hline $\mathbf{1 2}$ & Empathy & 5.48 \\
\hline $\mathbf{1 3}$ & The ease of establishing contacts & 5.08 \\
\hline 14 & Communication skills & 5.51 \\
\hline 15 & Striving for perfection and continuous improvement of the effects of one's & 5.68 \\
\hline & actions & \\
\hline & Source: own elaboration & \\
\hline
\end{tabular}

The winning competences are as follows: striving for perfection and continuous improvement of the effects of one's actions, self-improvement skills, communication skills, empathy, cooperation with others and creativity. Students generally seem to have a relatively good self-assessment of their competencies and skills.
The most important question tried to explore whether students are aware of the social sector organizations (see Table 3).

The average knowledge of responding students on social economy and non-profit sector seems to be relatively bad -4 out of 7 means are below the centre of the scale (the centre of the scale is the middle between compliance and non-compliance of the answers with the reality). Only 3 sentences were recognized more accurately by the respondents: more students know that social enterprises also employ managers, they know that social entrepreneurship means combining economic and social goals and they know that such organizations can make a profit.

Questionnaire also included a question about factors which can potentially enable respondents to set up their own social enterprises. As shown in table 4, the factors which may encourage surveyed students to establish a social enterprise are mainly: ability to work with liked people and ability to do things that are important and needed in society. Facing the new challenges, willingness to help other people and an innovative idea could also make students be more inclined to establish their own social businesses. Respondents are less interested in risk avoidance and professional help in establishing their own social enterprises. It suggests that students do not treat social enterprises as safe haven compared to traditional business. It also indicates that social factors have greater importance than ability to be the leader or a manager.

Table 3 Knowledge and awareness about the social sector (where 1 denotes respondent's opinion the least compliant with the reality; 7 denotes full compliance with reality)

\begin{tabular}{|c|c|c|}
\hline No. & $\begin{array}{l}\text { Verified element of knowledge on the basis } \\
\text { of the following sentences }\end{array}$ & Mean \\
\hline 1 & People usually work voluntarily in non-governmental organizations & 3.49 \\
\hline 2 & Social entrepreneurship is an organization that does not make a profit & 4.07 \\
\hline 3 & Social enterprises are not competitive with typical business enterprises & 3.81 \\
\hline 4 & Social enterprises are the form of social aid & 3.68 \\
\hline 5 & People at risk of social exclusion usually work in social enterprises & 3.86 \\
\hline 6 & Social enterprises do not employ a manager & 5.10 \\
\hline 7 & Social entrepreneurship combines economic and social goals & 4.67 \\
\hline
\end{tabular}

Table 4 Factors that may contribute to the establishment of one's own social enterprise

\begin{tabular}{|l|c|}
\hline Factor & Percentage \\
\hline I would want to help other people & $38.1 \%$ \\
\hline I would be able to work with people I like & $42.5 \%$ \\
\hline An innovative idea & $35.8 \%$ \\
\hline The ability to do things that are important and needed in society & $41.0 \%$ \\
\hline I would want to take on new challenges & $39.6 \%$ \\
\hline The possibility of receiving support for activities from public funds & $29.1 \%$ \\
\hline I would want to check myself in the role of a manager of the & $23.9 \%$ \\
\hline organization & $27.6 \%$ \\
\hline Independence in making decisions & $18.7 \%$ \\
\hline Less risk than in a typical business & $17.2 \%$ \\
\hline Someone's help in establishing the organization &
\end{tabular}

Source: own elaboration 
Table 5 Kendall's Tau-b Correlation Coefficient

\begin{tabular}{|c|c|c|c|c|c|c|c|c|}
\hline \multirow{2}{*}{\multicolumn{2}{|c|}{ Factor no. }} & \multicolumn{7}{|c|}{ Knowledge and awareness about the social sector (legend is in table 3 ) } \\
\hline & & \multirow{2}{*}{$\begin{array}{c}1 \\
-0.02\end{array}$} & \multirow{2}{*}{$\frac{2}{0.00}$} & \multirow{2}{*}{$\begin{array}{c}3 \\
-0.01\end{array}$} & \multirow{2}{*}{$\begin{array}{c}4 \\
-0.09\end{array}$} & \multirow{2}{*}{$\begin{array}{c}5 \\
-0.14^{*}\end{array}$} & \multirow{2}{*}{$\begin{array}{c}6 \\
-0.07\end{array}$} & \multirow{2}{*}{$\begin{array}{c}7 \\
-0.03\end{array}$} \\
\hline \multirow{6}{*}{$\begin{array}{l}\text { Factors determining the choice } \\
\text { of employer (legend is in table 1) }\end{array}$} & 1 & & & & & & & \\
\hline & 10 & -0.01 & 0.07 & 0.07 & -0.01 & 0.03 & 0.00 & $0.23^{* *}$ \\
\hline & 11 & 0.03 & 0.04 & -0.01 & 0.03 & 0.03 & -0.07 & $0.16^{*}$ \\
\hline & 12 & 0.03 & 0.13 & 0.06 & 0.05 & -0.01 & -0.04 & $0.16^{*}$ \\
\hline & 14 & -0.08 & $-0.15^{*}$ & -0.09 & -0.11 & 0.11 & 0.03 & 0.03 \\
\hline & 16 & 0.05 & 0.02 & $0.15^{*}$ & 0.00 & 0.02 & -0.10 & 0.10 \\
\hline \multirow{13}{*}{$\begin{array}{l}\text { Entrepreneurship competences } \\
\text { (legend is in table 2) }\end{array}$} & 2 & $0.14^{*}$ & $0.14^{*}$ & 0.09 & $0.16^{*}$ & 0.01 & 0.09 & 0.01 \\
\hline & 3 & 0.09 & 0.04 & $0.14^{*}$ & 0.03 & -0.06 & -0.03 & 0.03 \\
\hline & 4 & $0.17^{*}$ & 0.06 & 0.00 & 0.05 & 0.07 & -0.02 & 0.03 \\
\hline & 5 & $0.15^{*}$ & -0.01 & 0.01 & $0.14^{*}$ & 0.09 & -0.05 & 0.00 \\
\hline & 6 & $0.15^{*}$ & 0.03 & $0.14^{*}$ & $0.18^{* *}$ & -0.01 & 0.00 & -0.08 \\
\hline & 7 & $0.17^{*}$ & -0.04 & 0.05 & 0.07 & 0.07 & -0.02 & 0.02 \\
\hline & 8 & $0.17^{*}$ & 0.01 & 0.04 & 0.02 & 0.12 & -0.01 & -0.02 \\
\hline & 9 & $0.21^{* *}$ & -0.05 & 0.03 & 0.01 & 0.03 & -0.02 & 0.10 \\
\hline & 10 & $0.20^{* *}$ & 0.01 & 0.11 & -0.01 & 0.04 & -0.01 & $0.15^{*}$ \\
\hline & 11 & 0.11 & 0.10 & $0.17^{*}$ & 0.09 & 0.02 & 0.01 & 0.12 \\
\hline & 12 & 0.13 & 0.10 & 0.09 & 0.01 & 0.02 & -0.05 & $0.17^{*}$ \\
\hline & 13 & $0.17^{*}$ & 0.05 & 0.04 & 0.06 & 0.08 & -0.01 & 0.10 \\
\hline & 15 & $0.14^{*}$ & 0.04 & 0.03 & 0.08 & 0.05 & -0.04 & 0.03 \\
\hline
\end{tabular}

Source: own elaboration

** correlation is significant at the 0.01 level (2-tailed); ${ }^{*}$ correlation is significant at the 0.05 level (2-tailed)

Table 6 Test statistics for knowledge and awareness about the social sector variables

\begin{tabular}{|l|c|c|c|c|c|c|c|c|}
\hline \multirow{2}{*}{ Test Statistic** } & \multicolumn{7}{|c|}{ Knowledge and awareness about the social sector (legend is in table 3) } \\
\cline { 2 - 9 } & 1 & 2 & 3 & 4 & 5 & 6 & $1,152.0$ \\
\hline Mann-Whitney U & $1,497.0$ & $1,576.5$ & $1,638.5$ & $1,746.0$ & $1,672.0$ & $1,369.0$ \\
\hline Wilcoxon W & $6,153.0$ & $6,232.5$ & $6,294.5$ & $6,402.0$ & $2,413.0$ & $5,808.0$ & $6,025.0$ \\
\hline Z & -1.646 & -1.252 & -0.934 & -0.393 & -0.763 & -3.410 & -2.290 \\
\hline Asymp. Sig. (2-tailed) & 0.100 & 0.210 & 0.350 & 0.694 & 0.445 & 0.001 & 0.022 \\
\hline
\end{tabular}

Source: own elaboration

* Grouping Variable: Have you participated in course aimed at preparation of students to enter the labour market?

In the next step of the research, authors verified the strength and direction of association that exists between the factors determining the choice of the employer, entrepreneurship competences and knowledge and awareness about the social sector (see Table 5).

The most statistically significant correlations were observed between the entrepreneurship competence factors and the feature of the social sector. In general, students who have higher: ability to analyse the market, selfimprovement skills, ability to build a professional network of contacts, ability to advise, ease of establishing contacts, skills in negotiations, leadership and management are tend to have better knowledge that in non-governmental organizations, people can get paid work. Better knowledge about combining economic and social goals in social entrepreneurship is typical for students with higher empathy and ability to advice and those who attach more importance to social activities and compliance of organizational and personal values when choosing an employer. Correlations between other factors describing knowledge and awareness about the social sector and factors determining the choice of the employer and entrepreneurship competences are not significant or they are relatively weak.

Authors also examined whether participation in courses aimed at preparation of students to enter the labour market affects the knowledge and awareness about the social sector (see Table 6).

The obtained results ( $p$-value $<0.05$ ) suggest that students who participated in the course aimed at preparation to enter the labour market had better knowledge in terms of 1) combining social and economic goals in social enterprises and 2) understanding that social enterprises employ managers; than students who do not participate in such course. In terms of 5 other sentences describing the knowledge of social sector we did not observe significant differences among the students participating and not participating in such courses. 


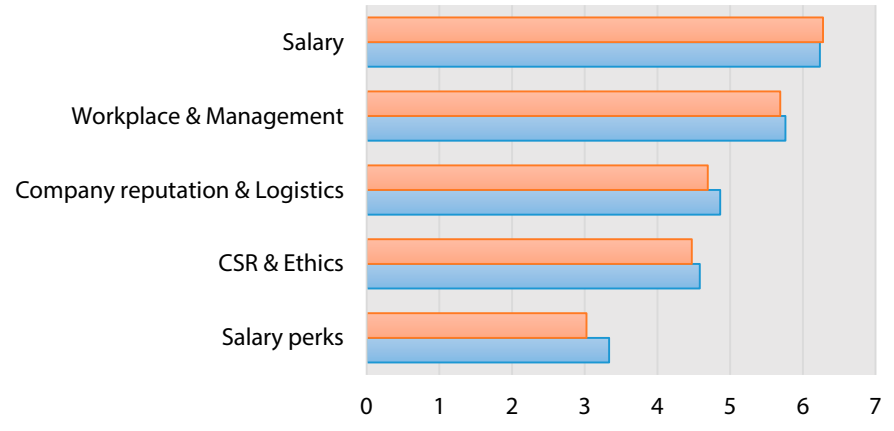

$\square$ Students from non-economic field of study $\square$ Students from economic field of study

Figure 2 Attractiveness of potential employer attributes (aggregated; 1 denotes: totally not important and 7 denotes: very important)

Source: Reichel and Socha, 2018 and own elaboration

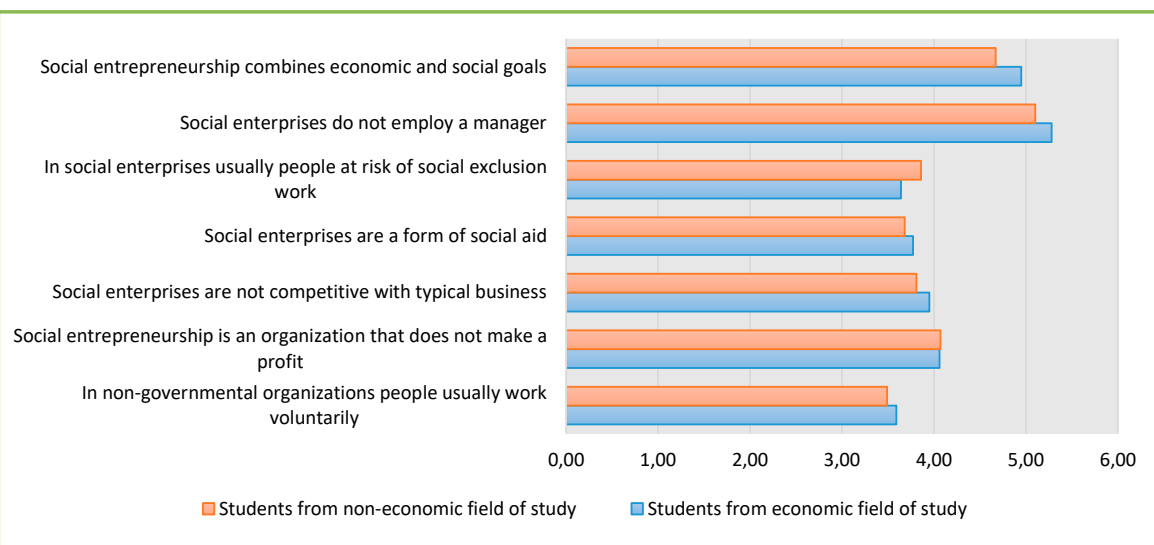

Figure 3 Knowledge and awareness about the social sector (where 1 denotes respondent's opinion the least compliant with the reality; 7 denotes full compliance with reality) Source: Reichel and Socha, 2018 and own elaboration

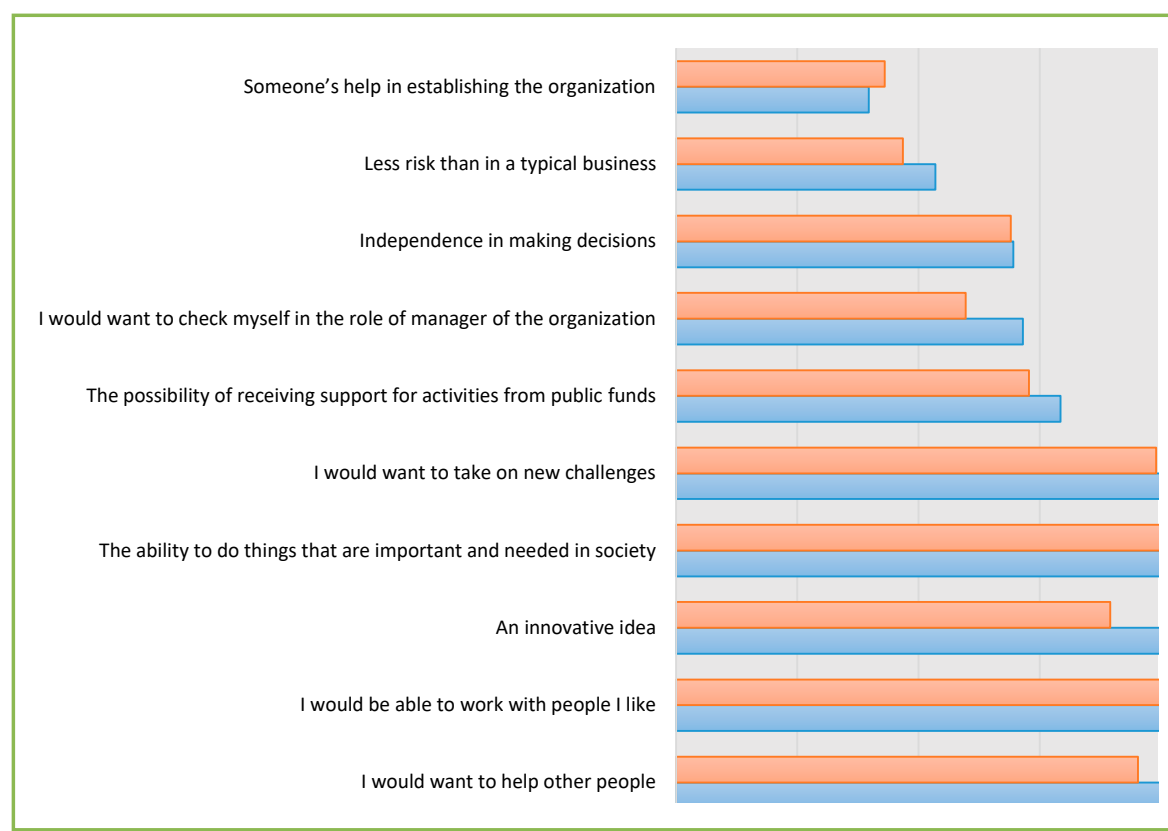

Figure 4 Factors that may contribute to establishment of one's own social enterprise Source: Reichel and Socha, 2018 and own elaboration
The conducted research confirmed that graduating students from non-economic fields of study consider different sectors as their future workplaces. What is interesting, over half of the respondents want to work outside the business sector. On the other hand, only a few people are going to apply for a job in NGOs and social enterprises (3.73\%). It supports the opinion that the third sector is not perceived as an important element of the labour market among young people studying non-economic subjects. As shown on the Figure 2, the most important for students from both non-economic and economic field of study (Reichel and Socha, 2018) are work related factors like salary, prospects of development and company image. CSR and ethics related issues with salary perks are still less important attributes in students' eyes.

Additionally, the respondents have a low knowledge about social enterprises. The weak awareness of social sector is related to voluntary activities that people do in this kind of organizations. It means that students associate social enterprises with social aid rather than a typical business. It suggests that the concept of social economy is still not properly promoted in Poland. People do not consider social enterprises as possible places for their career development. They are not familiar with structure and characteristics of this kind of organizations.

Obtained results are comparable to those presented by Reichel and Socha (2018) on the sample of students from economic field of study (see Figure 3). It suggests that the idea of social economy and social entrepreneurship is not sufficiently widespread both, in economic and non-economic fields of study.

Relatively low level of knowledge about social economy may be the reason why only a small percentage of students consider choosing a job in this sector. The results in the area of factors contributing to establishment of one's own social enterprise (see Figure 4) also show that majority of students treat social enterprises as a way to help other people or a way to do something important for a local community rather than combine social and economic goals.

\section{Conclusion}

We believe that future employees have different expectations from employers. They are looking for organizations which, besides the salary, comply with ethical standards and guarantee a good atmosphere at work. Greater emphasis on the non-wage factors could cause changes in the labour market in favour of social organizations. 
Despite the fact that there were people from non-economic studies in the surveyed group, they highly assessed their characteristics related to entrepreneurship. It means that students have rather positive attitude towards their skills and competences regarding the ability to establish, have or develop business organizations. The research results show that the higher assessment of one's own entrepreneurial characteristics, the better knowledge about social sector students have (statistically significant but weak correlation). Study revealed that courses dedicated to labour market orientation and career planning resulted in better understanding of the social sector (in 2 out of 7 characteristics).

The general conclusion from the research is that the elements of economic education should be also a part of higher education in non-economic fields of studies (preparation to act on the labour market, understanding business and economy). It brings benefits for people who are going to start their professional career in business but additionally, it improves the general knowledge about social enterprises and broadens the spectrum of workplaces as future choices. Unfortunately, for now, social economy sector in Poland does not seem to be a viable alternative for student choosing their jobs.

\section{Acknowledgements}

The paper was created in relation to activities of the project "OPEN MIND gamified platform and open online course in Social Entrepreneurship for female learners and students from diverse fields of study" (nr: 2016-1-BG01KA203-023754), supported by the European Commission funds under the Erasmus+ program. This publication reflects the views only of the author, and the Commission cannot be held responsible for any use which may be made of the information contained therein. The research, publication and conference participation is financed by the Polish Ministry of Science and Higher Education from financial resources for science in the years 2017-2018 granted for the implementation of an international co-financed project (nr. 3774/Erasmus+/2017/2).

\section{References}

BITNER, M. - STAROŚCIK, R. - SZCZERBA, P. 2016. Czy robot zabierze ci pracę? Sektorowa analiza komputeryzacji i robotyzacji europejskich rynków pracy. WISE Institiute, 2016.

BORZAGA, C. - BODINI, R. - CARINI, C. - DEPEDRI, S. - GALERA, G. - SALVATORI, G. 2014. Europe in Transition: The Role of Social Cooperatives and Social Enterprises. In Euricse Working Papers, vol. 69, 2014, no. 14.

BRANCO, D. 2007. Analiza potrzeb ekonomicznych, szkoleniowych i edukacyinych w sektorze ekonomii społecznej i przedsiębiorczości społecznej dla Słowenii, Włoch, Wlk. Brytanii i Polski. Raport zbiorczy, EU TESES. http://www.teses.eu/ (acces: 15. 6. 2009).

CARROLL, A. B. - SHABANA, K.M. 2010. The Business Case for Corporate Social Responsibility: A Review of Concepts, Research and Practice. In International Journal of Management Reviews, vol. 12, 2010, no. 1, pp. 85-105.

DEFOURNY, J. - NYSSENS, M. 2008. Social enterprise in Europe: recent trends and developments. In Social Enterprise Journal, vol. 4, no. 3, pp. 202-228.

EBERHARD, B. - PODIO, M. - ALONSO, A.P. - RADOVICA, E. - AVOTINA, L. - PEISENIECE, L. - SENDON, M.C. - LOZANO, A.G. - SOLÉ-PLA, J. 2017. Smart work: The transformation of the labour market due to the fourth industrial revolution (I4.0). In International Journal of Business and Economic Sciences Applied Research, vol. 10, 2017, pp. 47-66.

FREY, C.B. - OSBORNE, M. - HOLMES, C. 2016. Technology at work v2.0: the future is not what it used to be, Oxford Martin Programme on Technology and Employment. Oxford: Oxford Martin School and Citi GPS, 2016. http://www.oxfordmartin.ox.ac.uk/ publications/view/2092 (access: 9.04.2018).

GAZETA PRAWNA. 2017. Humaniści przyszłością rynku pracy? Na to wskazują badania. http://serwisy.gazetaprawna.pl/praca-i-kariera/artykuly/1071598, humanisci-narynku-pracy-umiejetnosci-miekkie.html (access: 9.04.2018).

GUS. 2018. Informacja 0 sytuacji społeczno-gospodarczej kraju w 2017 r. http://stat. gov.pl/download/gfx/portalinformacyjny/pl/defaultaktualnosci/5498/1/68/1/ informacja 0 sytuacji spoleczno-gospodarczej kraju w 2017 r.pdf (access: 23.02.2018).

HAUGH, H. 2005. The role of social enterprise in regional development. In International Journal of Entrepreneurship and Small Business, vol. 2, 2005, no. 4.

KAŹMIERCZAK, T. - RYMSZA, M. (eds.) 2007. Kapitał społeczny. Warszawa : Ekonomia społeczna, ISP, 2007.

LEŚ, E. 2005. Nowa ekonomia społeczna. In Wybrane koncepcje, Trzeci Sektor, 2005, no. 2, pp. 36-44.

MANYIKA, J. - LUND, S. - CHUI, M. - BUGHIN, J. - WOETZEL, J. - BATRA, P. - KO, R. - SANGHVI, S. 2017. What the future of work will mean for jobs, skills, and wages. https://www.mckinsey.com/global-themes/future-of-organizations-and-work/ what-the-future-of-work-will-mean-for-jobs-skills-and-wages (access: 28.02.2018).

MGI (McKinsey Global Institute). 2017. Jobs lost, jobs gained: workforce transitions in a time of automation, McKinsey \& Company. https://www.mckinsey.com/ /media/ mckinsey/global\%20themes/future\%20 of\%20organizations/what $\% 20$ the $\% 20$ future $\% 20$ of $\% 20$ work $\% 20$ will\%20mean $\% 20$ for $\% 20$ jobs $\% 20$ skills $\% 20$ and $\% 20$ wages/mgi\%20jobs\%20lost-jobs\%20gained report december\%202017.ashx, (access: 28.02.2018).

MONZÓN, J.L. - CHAVES, R. (ed.) 2017. Recent evolutions of the Social Economy in the European Union. CIRIEC-International, 2017.

OCZEKIWANIA PRACODAWCÓW wobec absolwentów uczelni wyższych. 2016. http://www.bk.us.edu.pl/sites/bk.us.edu.pl/files/imce/badania/Oczekiwania pracodawc\%(3\%B3w 2016.pdf (access: 9.04.2018).

RATAJCZAK, M. (ed.) 2017. Połowę pracujących Polaków mogą zastąpić roboty. Górnicy, kierowcy, rolnicy zagrożeni? https://www.money.pl/gospodarka/wiadomosci/ artykul/roboty-maszyny-automatyzacja-miejsca-pracy,249,0,2382585.html (access: 28.02.2018)

REICHEL, J. 2018. Sukcesja stanowisk kierowniczych w organizacjach pozarządowych. Łódź : Wyd. Uniwersytetu Łódzkiego, 2018, p. 34.

REICHEL, J. - SOCHA, B. 2018. Do students of management and economics consider choosing jobs in social economy organizations? In $21^{\text {st }}$ Interantional Scientific Conference "Enterprise and Competitive Environment", Conference Proceedings. Brno : Mendel University in Brno, 2018, pp. 538-549.

STANKIEWICZ, J. - SEILER, B. 2013. Profesjonalizacja, jako czynnik sukcesu polskich organizacji pozarządowych. In Zarządzanie i Finanse, vol. 4, 2013, no. 2, pp. 341-353.

STEWART, I. - DE, D. - COLE, A. 2014. Technology and people: The great job-creating machine, Deloitte. https://www2.deloitte.com/pl/pl/pages/technology-media-andtelecommunications/articles/technologie-a-czlowiek.html (access: 9.04.2018).

VISSER, W. 2010. The Age of Responsibility, CSR 2.0 and the New DNA of Business. In Journal of Business Systems, Governance and Ethics, vol. 5, 2010, no. 3, pp. 1-17.

Wyborcza.pl 2015. Bezrobotny jak geograf. Zobacz, po których kierunkach najtrudniej znaleźć pracę, http://trojmiasto.wyborcza.pl/trojmiasto/1,35612,17264247,Bezrob otny jak geograf Zobacz po ktorych kierunkach.html (access: 9.04.2018).

\section{Contact address}

Janusz Reichel PhD, Faculty of Management, University of Łódź, Matejki 22/26, Łódź, Poland, 踏 +48 426356339 , e-mail: janusz.reichel@uni.lodz.pl 